\title{
Effect of feeding haylage on milk and beef quality indices
}

\author{
Irina Mironova ${ }^{1,2}$, Azat Nigmatyanov $^{3}$, Elena Radchenko $^{2, *}$, Natalya Gizatova ${ }^{1}$ \\ ${ }^{1}$ Federal State Budgetary Educational Institution of Higher Education "Bashkir State Agrarian \\ University". Russian Federation, 450001, Ufa, ul. 50-letia Oktyabrya, 34 \\ ${ }^{2}$ Federal State Research Institute of the Federal Penitentiary Service of the Russian Federation, \\ Russian Federation, 125130, Moscow, Narvskaya str., 15 A \\ ${ }^{3}$ Federal State Budgetary Educational Institution of Higher Education "Ufa State Petroleum \\ Technological University”, Russian Federation, 450078, Ufa, ul. Chernyshevskogo, 145.
}

\begin{abstract}
The 'Silos' software package was used to formulate diets for all of the animals involved in the study. Cows of the Holstein black-and-white breed were divided into three groups. They were fed grain and legume haylage conserved with the biological fermentation products 'Biosib' and 'Silostan'. The milk samples were analysed for chemical composition and physico-chemical properties. It was found that compared to the control group the samples of milk obtained from the test groups contained more dry matter (by $0.08 \%$ and $0.13 \%$ ), milk-solids-nonfat (by $0.04 \%$ and 0.06 $\%$ ), fat (by $0.04 \%$ and $0.07 \%$ ), fat (by $0.01 \%$ and $0.03 \%$ ), lactose (by $0.02 \%$ and $0.03 \%)$, energy value was larger by $0.56 \mathrm{kcal}(0.77 \%)$ and $0.98 \mathrm{kcal}(1.35 \%)$. The quality of raw meat was assessed after the control slaughter of the black-and-white bull calves aged 18 months. Before slaughter the animals were fed alfalfa haylage conserved with the biological fermentation product 'Biotrof' at doses of 2, 4 and 61 of the process solution per 1 ton of the grass. Compared to the control group the average meat samples obtained from the $1 \mathrm{st}-3 \mathrm{rd}$ test groups contained more dry matter (by 0.48-1.03\%), fat (by 0.29-0.84 \%), protein (by 0.25 $0.63 \%$ ), maturity rate was higher by $0.55-1.55 \%$, energy value per $1 \mathrm{~kg}$ of meat was higher by $155-436 \mathrm{~kJ}(2.03-5.70 \%$; $\mathrm{P} \leq 0.05)$.
\end{abstract}

\section{Introduction}

The present day Russian cattle industry should be based on highly productive livestock in order to be competitive and cost-efficient on the market and ensure the country's food independence. Animal productivity depends both on heredity and environmental conditions, primarily on feeding [1-5]. Over the past decades, Holstein black-and-white cows have demonstrated higher lactation indices than cows of other dairy breeds [6-7].

Ensuring proper feeding of animals one should take the quality of feeds into account. First of all it concerns the feeds preserved as silage and haylage as they are most negatively affected by harvesting and storage technology factors. It is essential to find the right method of the feed conservation by using new and more effective conservatives. The conservatives

\footnotetext{
*Corresponding author: helenr2003@mail.ru
} 
should be of low cost, safe to use and have the potential to enrich the feed with certain substances and increase the nutritional value of the feed. It will result in higher efficiency of nutrient use and better animal productivity [8].

Food security is discussed in terms of providing the population with sufficient food and ensuring the right of everyone to have access to safe food. The Rome declaration on world food security indicates that the state is to ensure the right of everyone to have access to safe and nutritious food [9].

In this regard the aim of our study was to assess the quality of milk and beef in animals fed the haylage conserved with different biological conservatives.

\section{Materials and methods}

The diet was formulated using the software package 'Silos', developed by D.A. Blogov, a candidate of biological sciences. The software package comprising 4 modules helps to save time on calculations and responds quickly to changes in the quality of the feed $[10,11]$.

Two series of experiments were performed to assess the effect of the conservatives on the haylage.

One of the experiments was performed on the cooperative farm 'Alga' in Chekmagushevskiy district of the Republic of Bashkortostan, Russia in 2016-2017. Tenmonth-old bull calves of the black and white breed were used in the scientific farm based experiment. They were divided into four groups on the similarity basis. The diet of the test groups contained alfalfa haylage conserved with the biological fermentation product 'Biotrof' at doses of 2, 4, 61 of the process solution per 1 ton of the grass. The bull calves of the control group were fed haylage without conservatives.

The second experiment was performed on the farm OOO (LLC) 'Bairamgul' in Uchalinskiy district of the Republic of Bashkortostan, Russia, in the same period. Thirty six Holstein black and white cows were used in the experiment. They were divided into three groups. The animals were kept in the same maintenance conditions, but were fed different diets. The control group was fed grain legume haylage without conservatives, the 1st test group was fed the haylage conserved with 'Biosib' biological frementation product, the 2nd test group was fed the haylage conserved with 'Silostan' biological fermentation product.

'Biotrof' product is a biological fermentation product based on pure culture of propionic bacteria used for silage. 'Biosib' product consists of lactic acid and propionic bacteria. 'Silostan' product comprises Lactobacillus plantarum and Lactobacillus casei lactic bacteria, Bacillus subtilis spore-forming bacteria and a complex of amino acids, enzymes, vitamins and trace elements.

In the 2nd lactation month $500 \mathrm{ml}$ of milk was sampled and assessed using the conventional methods.

Three 18-month-old bull calves in each group were slaughtered to assess the quality of meat. The average ground meat samples were taken for chemical analysis. The following indices were analysed: moisture, protein, fat and ash.

\section{Results}

The composition of milk and quality of dairy products is known to largely depend on the diet. This is due to the fact that microorganisms inhabiting the rumen of ruminants secrete enzymes that change the feed nutrients significantly. So the nutritional balance of the diet has a direct effect on the microorganisms, fermentation processes, the volatile fatty acid ratio and finally on milk productivity, physico-chemical and technological properties of milk $[12,13]$. 
The study revealed that 'Bosib' and 'Silostan' conservatives used for grain and legume haylage had a positive effect on the milk composition and characteristics (Table 1).

Table 1. Chemical composition and quality indices of cows' milk $(\mathrm{X} \pm \mathrm{Sx})$

\begin{tabular}{|l|c|c|c|}
\hline \multirow{2}{*}{\multicolumn{1}{|c|}{ Index }} & \multicolumn{3}{c|}{ Group } \\
\cline { 2 - 4 } & control & 1 st test & 2nd test \\
\hline Acidity, ${ }^{\circ} \mathrm{T}$ & $16.94 \pm 0.040$ & $16.99 \pm 0.036$ & $17.02 \pm 0.037$ \\
\hline Density, $^{\circ} \mathrm{A}$ & $28.35 \pm 0.184$ & $28.64 \pm 0.111$ & $28.73 \pm 0.098$ \\
\hline Moisture, \% & $87.49 \pm 0.052$ & $87.41 \pm 0.057$ & $87.36 \pm 0.023 *$ \\
\hline Dry matter, \% & $12.51 \pm 0.052$ & $12.59 \pm 0.057$ & $12.64 \pm 0.023 *$ \\
\hline MSNF, \% & $8.70 \pm 0,025$ & $8.74 \pm 0.052$ & $8.76 \pm 0.029$ \\
\hline Mass fraction of fat, \% & $3.81 \pm 0.035$ & $3.85 \pm 0.021$ & $3.88 \pm 0.023$ \\
\hline Mass fraction of protein, \% & $3.18 \pm 0.010$ & $3.19 \pm 0.007$ & $3.21 \pm 0.004 *$ \\
\hline Lactose, \% & $4.69 \pm 0.027$ & $4.71 \pm 0.039$ & $4.72 \pm 0.022$ \\
\hline Ash, \% & $0.83 \pm 0.021$ & $0.84 \pm 0.013$ & $0.83 \pm 0.016$ \\
\hline Calorie value, kcal & $72.83 \pm 0.392$ & $73.39 \pm 0.291$ & $73.81 \pm 0.198$ \\
\hline Calcium, mg\% & $126.12 \pm 1.115$ & $128.24 \pm 0.383$ & $128.71 \pm 0.259$ \\
\hline Phosphorus, mg\% & $92.40 \pm 1.255$ & $93.00 \pm 0.791$ & $93.60 \pm 0.837$ \\
\hline Calcium-Phosphorus ratio & $1.37 \pm 0.024$ & $1.38 \pm 0.012$ & $1.38 \pm 0.010$ \\
\hline
\end{tabular}

The titratable milk acidity level was measured in all of the milk samples as its index depends on the diet and is considered as a criterion of fresh milk. All of the samples were in line with the current standard requirements. However, milk acidity in the test samples was higher by $0.05^{\circ} \mathrm{T}(0.30 \%)$ and $0.08^{\circ} \mathrm{T}(0.47 \%)$. The higher indices can be accounted for by the increased protein in the milk obtained from the test group animals.

Milk density is determined by the dry matter content, so the density value was within the standard range but by $0.29^{\circ} \mathrm{A}(1.02 \%)$ and $0.38^{\circ} \mathrm{A}(1.34 \% ; \mathrm{P} \leq 0.05)$ higher in the test samples than in the control sample. Dry matter in the milk samples obtained from the $1 \mathrm{st}$ and 2 nd test groups was by $0.08 \%$ and $0.13 \%$ higher than in the control sample.

Milk-solids-nonfat (MSNF) indicates biological value of milk. The conserved haylage had a positive effect on the MSNF value. The MSNF value was $8.70 \%$ in the control sample, the index was by $0.04 \%$ and $0.06 \%$ lower than in the test samples.

A similar pattern was revealed in the mass fractions of fat, protein and lactose. In the 1st test sample the fat mass fraction was by $0.04 \%$ higher than in the control sample, in the 2nd test sample the value was by $0.07 \%$ higher than in the control sample. The protein mass fraction was by $0.01 \%$ and $0.03 \%$ higher in the test samples than in the control sample. The lactose value was by $0.02 \%$ and $0.03 \%$ higher in the test samples than in the control sample.

The samples demonstrated no significant differences in ash.

The increased nutrients in the test samples resulted in higher energy value of milk. The energy value in the 1 st test sample was by $0.56 \mathrm{kcal}(0.77 \%)$ higher than in the control sample, the energy value in the 2 nd test sample was by $0.98 \mathrm{kcal}(1.35 \%)$ higher than in the control sample.

Calcium as the main abundant mineral found in milk has good digestibility and is balanced with phosphorus. Intergroup differences in calcium and phosphorus were found. 
Milk samples obtained from the cows fed the conserved haylage showed higher calcium and phosphorus indices than the control sample. The calcium value was by $2.12 \mathrm{mg} \%$ higher in the 1st test sample and by $2.59 \mathrm{mg} \%$ higher in the 2nd test sample than in the control sample. The phosphorus value was by $0.60 \mathrm{mg} \%$ higher in the 1 st test sample and by $1.20 \mathrm{mg} \%$ higher in the 2 nd test sample compared to the control sample.

The calcium and phosphorus ratio was optimal in the 1.37-1.38 range in all of the milk samples.

In terms of organoleptic properties all of the milk samples had yellowish tinted white colour. The taste of milk was pure, typical of fresh raw milk without foreign flavours and smells. Milk was visibly homogeneous without any flakes and sediment.

Beef quality is known to be affected by the diet and the feed quality [14]. To assess the chemical composition of meat (ground meat) the scientific and farm-based experiment was performed on the black and white bull calves fed the haylage conserved with 'Biotrof' biological fermentation product in different concentrations. (Figure 1).

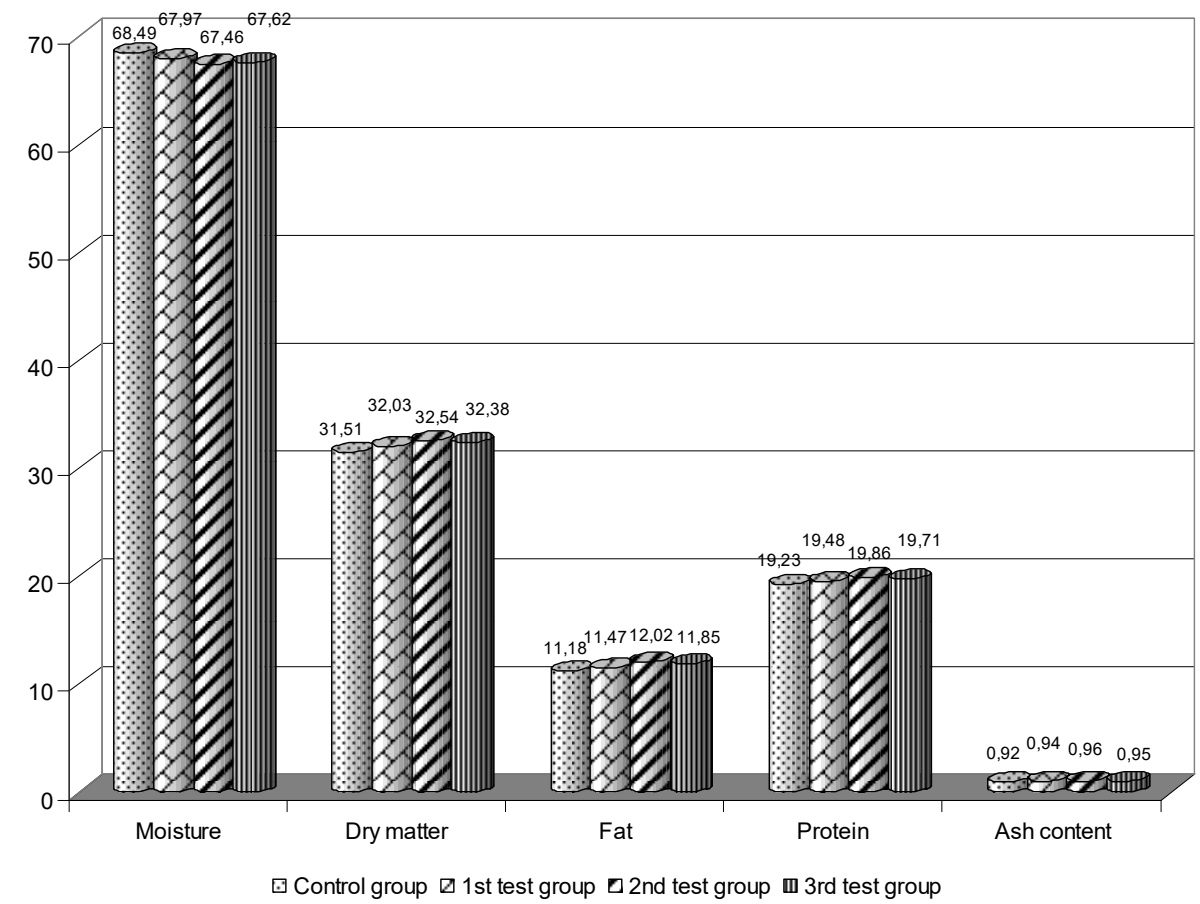

Fig. 1. Chemical composition of the average meat sample (ground beef), $\%$

The 1st, 2nd and 3rd test groups had more dry matter (by $0.48 \%, 1.03 \% \mathrm{P} \leq 0.05 ; 0.87$ $\%$, respectively) in the average meat sample than the control group. A similar intergroup difference was observed in the fat and protein content. The fat value was by $0.29-0.84 \%$ higher in the test samples than in the control sample; the protein value was by $0.25-0.63 \%$ higher in the test samples than in the control sample.

The test samples contained more ash in meat than the control sample. The mineral content was $0.92 \%$ in the control sample; the value was by $0.02 \%, 0.04 \%$ and $0.03 \%$ lower than in the 1st, 2nd and 3rd test groups, respectively.

The moisture-fat ratio in meat indicates the meat maturity rate, i.e. the optimal age of animals slaughtered. The maturity rate of $17-25$ is found in moderately marbled meat. The control group showed the lowest value of the maturity rate (16.32), the value was by 0.55 , $1.50,1.21 \%$ lower than in the $1 \mathrm{st}, 2 \mathrm{nd}, 3 \mathrm{rd}$ test groups, respectively. 
The specific weight of nutrients in meat was higher in the test group samples, so higher protein and fat values were found in the edible carcass parts in the test samples (Table 2).)

Table 2. Nutrient yield and energy value of meat in bull calves

\begin{tabular}{|c|c|c|c|c|}
\hline \multirow{3}{*}{ Index } & \multicolumn{4}{|c|}{ Group } \\
\hline & \multirow{2}{*}{ control } & \multicolumn{3}{|c|}{ test } \\
\hline & & $1 \mathrm{st}$ & 2nd & 3rd \\
\hline $\begin{array}{c}\text { Meat contains: } \mathrm{kg} \\
\text { protein }\end{array}$ & $19.82 \pm 0.74$ & $20.65 \pm 0.32$ & $\begin{array}{l}21.72 \pm 0.22 \\
*\end{array}$ & $21.40 \pm 0.52$ \\
\hline fat & $11.51 \pm 0.30$ & $12.15 \pm 0.18$ & $\begin{array}{c}13.15 \pm 0.26 \\
* *\end{array}$ & $\begin{array}{c}12.87 \pm 0.11 * \\
*\end{array}$ \\
\hline $\begin{array}{l}\text { Energy concentrated in } \\
1 \mathrm{~kg} \text { of meat, } \mathrm{kJ}\end{array}$ & $7653 \pm 137.3$ & $7808 \pm 61.3$ & $\begin{array}{c}8089 \pm 99.6 \\
*\end{array}$ & $7999 \pm 126.0$ \\
\hline $\begin{array}{l}\text { including: } \\
\text { protein energy, } \mathrm{kJ}\end{array}$ & $3302 \pm 71.1$ & $3343 \pm 32.3$ & $3409 \pm 28.1$ & $3383 \pm 81.0$ \\
\hline protein energy, kJ & $4352 \pm 71.8$ & $4465 \pm 69.3$ & $4680 \pm 74.5$ & $4615 \pm 48.1$ \\
\hline $\begin{array}{l}\text { Total energy in the } \\
\text { carcass meat, MJ }\end{array}$ & $\begin{array}{c}788.58 \pm 24.2 \\
9\end{array}$ & $\begin{array}{c}827.65 \pm 9.1 \\
0\end{array}$ & $\begin{array}{c}884.68 \pm 13 . \\
73\end{array}$ & $\begin{array}{c}868.27 \pm 13.2 \\
5\end{array}$ \\
\hline
\end{tabular}

The bull calves of the 1st, 2nd, 3rd groups had more protein in the muscle tissue than the control group animals by $0.53 \mathrm{~kg}(4.19 \%)$, by $1.90 \mathrm{~kg}(9.59 \%, \mathrm{P} \leq 0.05)$ and by $1.58 \mathrm{~kg}$ (7.97\%), respectively. The fat index was by $0.64 \mathrm{~kg}(5.56 \%) ; 1.64 \mathrm{~kg}(14.25 \% ; \mathrm{P} \leq 0.01)$ and $1.36 \mathrm{~kg}(11.82 \% ; \mathrm{P} \leq 0.01)$ higher in the $1 \mathrm{st}, 2 \mathrm{nd}$ and $3 \mathrm{rd}$ groups, respectively, than in the control group.

Intergroup differences in synthesis and accumulation of nutrients caused different energy levels in the meat of the experimental animals. The energy value of $1 \mathrm{~kg}$ of meat was $7653 \mathrm{MJ}$ in the control group, the value was lower by $155 \mathrm{~kJ}(2.03 \%)$ than in the $1 \mathrm{st}$ test group, by $436 \mathrm{~kJ}(5.70 \% ; \mathrm{P} \leq 0.05)$ lower than in the 2 nd test group and by $346 \mathrm{~kJ}$ $(4.52 \%)$ lower than in the 3 rd test group.

\section{Discussion}

The haylage conserved with the biological fermentation products 'Biosib' and 'Silostan' and fed to the Holstein black and white cows had a positive effect on the milk chemical composition and properties. 'Silostan' product demonstrated the best effect as it resulted in higher fat and protein values in milk, and increased food, biological and energy values.

The analysis showed that the meat samples obtained from the bull calves fed the conserved haylage had the optimal ratio of dry matter and moisture. Special attention should be paid to the protein-fat ratio when assessing nutritional value of meat. Some researchers think that high quality beef should have the protein-fat ratio at 1:0.6, other scientists consider the protein-fat ratio of 1:1 optimal. The result data showed that the control sample had the protein-fat ratio at 1:0.58, the protein-fat ratio was 1:0.59, 0.61 in the test samples. The quality of the meat obtained from all of the groups met the consumer's demands and the requirements of the meat processing industry.

The best effect was achieved due to the biological fermentation product 'Biotrof' used to conserve alfalfa haylage in concentration of 41 of the process solution per 1 ton of the grass.

\section{Conclusions}


In conclusion, different diets resulted in changes in the composition and properties of milk and meat. The animals fed the haylage conserved with biological conservatives showed the best indices. Our recommendations would be to add grain and legume haylage conserved with 'Silostan' product to the diet of cows and add alfalfa haylage conserved with 'Biotrof' product at 41 per 1 ton of the grass to the diet of bull calves.

\section{References}

1. A.V. Andreeva [et al.], Journal of Engineering and Applied Sciences, 13, 6467-6472 (2018)

2. F. Khaziahmetov [et al.], Journal of Engineering and Applied Sciences, 13, 6541-6545 (2018)

3. I.V. Mironova [et al.], Ministry of Agriculture of the Russian Federation, Federal State Budgetary Educational Institution of Higher Education 'Bashkir State Agrarian University (2016)

4. I.V. Mironova [et al.], Izvestiya Orenburgskogo gosudarstvennogo agrarnogo universiteta Bulletin of Orenburg state agrarian university, 5 (55), 127-129 (2015)

5. I.V. Mironova [et al.], Materialy regional'noy nauchno-prakticheskoy konferentsii, 101105 (2009)

6. Kh.Kh. Tagirov [et al.], Journal of Engineering and Applied Sciences, 13 (S8), 65976603 (2018)

7. I.V. Mironova [et al.], Research Journal of Pharmaceutical, Biological and Chemical Sciences, 9(6), 18-25 (2018)

8. Matti Siemiatycki, Naeem Farooqi, Journal of the American Planning Association, 78 (3), 286-299 (2012) doi:10.1080/01944363.2012.715525

9. I. A. Vizhina, A. A. Kin, and V. N. Kharitonova DOI: 10.1134/S2079970513010139

10. M. Bult-Spiering, G. Dewulf, Strategic Issues in Public-Private Partnerships: an International Perspective. Blackwell Publishing Ltd., 16-18 (2006)

11. Matti Siemiatycki, Naeem Farooqi, Journal of the American Planning Association, 78 (3), 286-299 (2012)

12. B. Eschenfelder, Nonprofit Management and Leadership, 21 (3), 273-288 (2011) doi: $10.1002 / \mathrm{nml} .20025$

13. Federal Law of July 13, 2015 No. 224-Federal law (as amended on July 26, 2019)

14. A. Berezin, B.S. Sergi, N. Gorodnova, Efficiency Assessment of Public-Private Partnership (PPP) Projects: The Case of Russia. Sustainability (Switzerland), 10(10), 3713 (2018) https://doi.org/10.3390/su10103713 